\title{
GOSSIP, DEFAMATION AND SODOMY IN THE EARLY MODERN SOUTHERN NETHERLANDS
}

\section{Introduction}

One early morning in 1494, Corneille Vander Poorten sent a shockwave through the city of Bruges. Under the cover of darkness, he posted an anonymous pamphlet on the doors of Bruges' stock exchange in which he accused the entire city of rampant sodomy. Corneille was a jack of all trades, master of none. Although a native of Brussels, Corneille had moved to Rome, where he worked as a cook for over a decade. Upon his return to the Netherlands, he found a new employer in Antwerp; yet shortly afterwards, Corneille was fired for thieving. He left Antwerp and decided to try his luck in Bruges, serving in the household of Corneille Pieters. Barely six weeks later, however, Corneille abandoned Pieters because he only gave him 'crap' to drink. His new master, Rolland de Vos, then dismissed him after two months without salary. Luckily, Corneille found a new job in the tavern of Jehan Camelle. Yet only a few days later he was accused of theft and imprisoned. Due to his time in jail and the fact that his former employers had apparently spread the word that Corneille was a dishonest man, he failed to find another job. At that point, it seems that Corneille decided to revenge himself upon the inhospitable citizens of Bruges. In three handwritten letters, attached to the entrance of the commercial heart of the city, he accused several public officers and notables along with 'le commun peuple de ladite ville de Bruges' of the 'villain pechie et criesme de zodomye'.

Corneille's defaming message caused a 'grand perturbacion'. Corneille not only insulted his former employers, he also implicated all citizens in his written indictment by claiming that sodomy predominated in Bruges, both clandestinely and openly. Naturally, the civic authorities were furious, but Corneille had anticipated their anger by fleeing for Tournai, a French enclave nearby the County of Flanders. The aldermen of Bruges notified their French colleagues, however, and Corneille was arrested. When it turned out that Corneille's handwriting matched the original libels, he was thoroughly interrogated. Corneille confessed to several thefts and explicitly withdrew his accusations against the citizens of Bruges. Interestingly, Corneille suddenly confessed that he himself had committed 'buggery'. While he was a teenager, he had engaged in sexual intercourse with a calf, and during his time in Rome he had had sex with several men. Consequently, the writer of the 'diffamatoires libelles et lettres sedicieuses' was sentenced to death by beheading. As Corneille mounted the scaffold on the Grand Place of Tournai, he recanted, a fact noted at length in the criminal records of the city of Bruges, which even had sent a delegation to attend the execution. ${ }^{2}$ In this intriguing case, the authorities had acted decisively, doing their utmost to put a stop to a rumour about

\footnotetext{
${ }^{1}$ Bruges, City Archives (CAB), Series 192 no. 1 (Verluydboek 1490-1537), fol. 10r; Marc Boone, 'State Power and Illicit Sexuality: The Persecution of Sodomy in Late Medieval Bruges', Journal of Medieval History 22 (1996), 137-38.

${ }^{2}$ CAB, Series 192 no. 1 fols. 10r-12r.
} 
deviant sexuality. At the same time, however, city councils often heavily depended upon similar forms of urban communication to discover actual instances of sodomy. ${ }^{3}$

The term 'sodomy' was applied to a wide range of sexual behaviours that were not aimed at procreation. It included homosexuality, but also non-vaginal sex between a man and a woman, bestiality, masturbation and paedophilia. While specific urban legislation regarding sodomy was lacking under Burgundian reign, it was generally punished by death by burning, a sentence that was recommended by several influential jurists in the region. Following the Constitutio Criminalis Carolina, the criminal code instituted by Emperor Charles V in 1532, sodomites were officially condemned to the stake throughout the Habsburg territories, including the Southern Netherlands. Because sodomites transgressed prevailing sexual boundaries, their crime was perceived as a sin against nature that had to be kept quiet. ${ }^{4}$

In spite of this imposed silence, this article argues that the unspeakable sin was a popular subject among slanderers. As the case of Vander Poorten shows, people often went to great lengths to defame fellow city dwellers as sexual deviants. Consequently, denunciation was a common way of identifying sodomites, and the authorities were often forced to take action because of local gossip. Using trial records and bailiff accounts dating from 1400 to $1700,{ }^{5}$ this article analyses the different ways in which rumours about sodomy were disseminated in early modern urban society. In doing so, this essay aims to nuance the idea that the political elites were the main engine behind the persecution of sodomites and reveals the important role urban gossip and sexual slander played in early modern sodomy trials. As will be demonstrated, the trial records analysed cannot always be taken at facevalue, although this makes them no less valuable as a source for studying social history, ${ }^{6}$ since they offer us the opportunity to analyse the discourses and strategies that repeatedly appear in early sodomy trials.

This article scrutinizes several related oral practices such as rumour, gossip and slander, although historiography has drawn considerable attention to the distinctions between these forms of

\footnotetext{
${ }^{3}$ Corneille Vander Poorten's case is unique in the region, but elsewhere supposed sodomites were occasionally defamed in public notes. In Florence for instance, the authorities installed so-called 'holes of truth' -openings in a wall of the Palazzo Vecchio- in which citizens could place written accusations. In 1476, none other than Leonardo da Vinci was accused of sexual relations with a boy through such a note. Because the anonymous informant never revealed himself, however, the charges were eventually dropped. James Saslow, Ganymede in the Renaissance: Homosexuality in Art and Society (New Haven: Yale University Press, 1986), 85.

${ }^{4}$ Tom Linkinen, Same-sex Sexuality in Later Medieval English Culture (Amsterdam: Amsterdam University Press, 2015), 86.

${ }^{5}$ Bailiffs were princely officers who had to present an annual account of their judicial activities to the princely Chamber of Accounts. Jan Van Rompaey, Het grafelijk baljuwsambt in Vlaanderen tijdens de Boergondische periode (Brussels: Paleis der Academiën, 1967).

${ }^{6}$ Robert Swanson, “"Et examinatus dicit...”: Oral and Personal History in the Records of English Ecclesiastical Courts', in Michael Goodich (ed.), Voices from the Bench. The Narratives of Lesser Folk in Medieval Trials (New York: Palgrave Macmillan, 2006), 204.
} 
communication. ${ }^{7}$ Gossip is generally considered a confidential form of communication between specific individuals, whereas rumours had a wider impact because they were aimed at a larger public and were anonymously spread throughout urban society. ${ }^{8}$ However, the differences between rumour, slander and gossip are not always easy to distinguish and their functions often overlapped. This was also the case in the Low Countries, where many cities had specific customary laws about deviant speech. Yet these laws did not necessarily make a distinction between anonymous gossip or direct insults. According to the fifteenth-century Brabantine jurist Willem van der Tanerijen for instance, both insult, defamation, gossip and hearsay warranted similar punishment. ${ }^{9}$ In the legal records analysed too, no clear distinction was made between anonymous rumours or identified gossipers. As such, this essay discusses these phenomena in a similar manner.

\section{Rumours and gossip in the early modern city}

Theoretically, gossiping was strongly condemned by early modern moralists. ${ }^{10}$ In Bruges, rhetorician plays were even performed in which the allegorical figure of gossip was strongly condemned. ${ }^{11}$ The fifteenth-century Flemish jurist Filips Wielant compared gossip, or 'injuries by words' to physical injuries and stated that it should be punished as such. ${ }^{12}$ In reality, the streets and squares in any given European city perpetually reverberated with numerous rumours on a variety of subjects. While gossiping was perceived as a typical female phenomenon in the early modern period, ${ }^{13}$ research has shown that this social activity was less strictly gendered and that early modern men also knew how to benefit from spreading rumours. ${ }^{14}$ Moreover, gossiping proved popular at every level of society. Not just the lower classes used defamations during quarrels, also urban elites and courtiers

\footnotetext{
${ }^{7}$ Claire Walker, 'Whispering Fama: Talk and Reputation in Early Modern Society', in Heather Kerr and Claire Walker (eds.), Fama and her Sisters: Gossip and Rumour in Early Modern Europe (Turnhout: Brepols: 2015), 16-19.

${ }^{8}$ Keith Bothelo, Renaissance Earwitnesses: Rumor and Early Modern Masculinity (New York: Palgrave Macmillan, 2009), 10.

${ }^{9}$ Willem van der Tanerijen, Boec der loopender practijken der raidtcameren van Brabant (Brussels: Paleis der Academiën, 1952), 129.

${ }^{10}$ Emily Butterworth, The Unbridled Tongue. Babble and Gossip in Renaissance France (Oxford: Oxford University Press, 2016), 8-9.

${ }^{11}$ Samuel Mareel, "You Serve Me Well': Representations of Gossip, Newsmongering and Public Opinion in the Plays of Cornelis Everaert', in Jan Bloemendal et al (eds.), Literary Cultures and Public Opinion in the Low Countries, 1450-1650. 37-53 (Leiden: Brill, 2011), 45.

${ }^{12}$ Filips Wielant, Corte instructie in materie criminele (Brussels: Paleis der Academieën, 1995), 267; Jelle Haemers, 'Filthy and Indecent Words. Insults, Defamations, and Urban Politics in the Southern Low Countries, 1300-1550', in Jan Dumolyn et al (eds.), The Voices of the People in Late Medieval Europe. Communication and Popular Politics (Turnhout: Brepols, 2014), 253-54.

${ }^{13}$ Bernard Capp, When Gossips Meet: Women, Family, and Neighbourhood in early Modern England (Oxford: Oxford University Press, 2004), 63; Susannah Lipscomb, 'Crossing Boundaries: Women's Gossip, Insults and Violence in Sixteenth-Century France', French History 25 (2011), 413; Sandy Bardsley, Venomous Tongues. Speech and Gender in Late Medieval England (Philadelphia: University of Pennsylvania Press, 2006), 77.

${ }^{14}$ Alexander Cowan, 'Gossip and Street Culture in Early Modern Venice', Journal of Early Modern History 12 (2008), 323; Susan Philips, Transforming Talk. The Problem with Gossip in Late Medieval England (University Park: Pennsylvania State University Press, 2007), 52.
} 
alike did not hesitate to gossip in order to make a political statement. ${ }^{15}$ This was especially true in the Southern Netherlands, where rumours played a significant role in the numerous urban uprisings that marked the region during the late Middle Ages. ${ }^{16}$ Subversive speech had the power to mobilize large groups within society. Consequently, urban governments were especially sensitive to rumours that criticized the functioning of the city administration. ${ }^{17}$

Civic authorities went to great lengths to suppress such rumours, often to no avail. After all, slandering messages were not only dispersed orally as the case of Corneille Vander Poorten illustrates. Particularly in times of popular rebellion, numerous politically charged pamphlets and handwritten libels circulated in the public domain, ${ }^{18}$ usually in the proximity of governmental or public buildings of symbolic significance, where they could be read by anyone. ${ }^{19}$ These written defamations were highly provocative because of their aggressive tone and the fact that the government's monopoly on public messages was broken by anonymous perpetrators. ${ }^{20}$ City councils vigorously attempted to identify these slanderers, including in depth analyses of the handwriting of such written libels. ${ }^{21}$

Although the civic authorities themselves were happy to know any new titbits and even dispatched messengers to this end, ${ }^{22}$ local citizens who were caught gossiping could be severely punished. In the Southern Netherlands, slanderers were often forced to undergo an amende honorable,

\footnotetext{
${ }^{15}$ Gilles Lecuppre and Élodie Lecuppre-Desjardin, 'La rumeur: un instrument de la compétition politique au service des princes de la fin du Moyen Âge', in Maïté Billoré and Myriam Soria (eds.), La rumeur au Moyen Âge. Du mépris à la manipulation ( $V^{e}-X V^{e}$ siècle) (Rennes: Presses Universitaires de Rennes, 2011), 157; Emily Butterworth and Hugh Roberts, 'Gossip and Nonsense in Renaissance France and England', Renaissance Studies 30 (2016), 14.

${ }^{16}$ Jan Dumolyn and Jelle Haemers, “A Bad Chicken was Brooding': Subversive Speech in Late Medieval Flanders', Past \& Present 214 (2012), 51. In early modern Venice then again, gossip turned out to be very useful in achieving communal peace and stability. Elizabeth Horodowich, 'The Gossiping Tongue: Oral Networks, Public Life and Political Culture in Early Modern Venice', Renaissance Studies 19 (2005), 44.

${ }^{17}$ Hannes Lowagie, 'Quetselike Maren.' De bestuurlijke reactie op geruchten in een laatmiddeleeuwse stad', Madoc 25 (2011), 34; David Cressy, Dangerous Talk: Scandalous, Seditious, and Treasonable Speech in PreModern England (Oxford: Oxford University Press, 2010), 27.

${ }^{18}$ On the interplay between oral and written polemics: Dumolyn and Haemers, "A Blabbermouth Can Barely Control His Tongue.' Political Poems, Songs and Prophecies in the Low Countries (Fifteenth-Sixteenth Centuries)', in Thomas Cohen and Lesley Twomey (eds.), Spoken Word and Social Practice. Orality in Europe (1400-1700) (Leiden: Brill, 2015), 280-99; Mathilde Bombart, 'When Writers Gossip: Authorial Reputation in the Literary Polemics of the French 1620s', Renaissance Studies 30 (2016), 137-51. Bombart also mentions a case of sodomite slurs among seventeenth-century writers.

19 Élodie Lecuppre-Desjardin, 'Des portes qui parlent. Placards, feuilles volantes et communication politique dans les villes des Pays-Bas à la fin du Moyen Âge', Bibliothèque de l'École des chartes 168 (2010), 151-72; Alastair Duke, 'Posters, Pamphlets and Prints: The Ways and Means of Disseminating Dissident Opinions on the Eve of the Dutch Revolt', Dutch Crossing 27 (2003), 28.

${ }^{20}$ Jacqueline van Leeuwen, 'Over slapscheten en levereters. Pamfletten en strooibriefjes in de laatmiddeleeuwse Vlaamse stad', Madoc 18 (2004), 78.

${ }^{21}$ Andrew Gordon, 'The Act of Libel: Conscripting Civic Space in Early Modern England', Journal of Medieval and Early Modern Studies 32 (2002), 388-89.

${ }^{22}$ Henk van Nierop, "And Ye Shall Hear of Wars and Rumours of Wars'. Rumour and the Revolt of the Netherlands,' in Judith Pollman and Andrew Spicer (eds.) Public Opinion and Changing Identities in the Early Modern Netherlands. Essays in Honour of Alastair Duke (Leiden: Brill, 2007), 75-76.
} 
a public ceremony in which they had to beg for forgiveness barefooted and holding burning candles. ${ }^{23}$ During this pacifying ritual, the slanderer was humiliated while the honour or authority of his victim was restored and, thereby, public peace was assured. ${ }^{24}$ Others were publicly exposed on the scaffold, fined, banned or forced to go on a pilgrimage. In some cases, the authorities felt that physical punishments were more appropriate, and so slanderers were sometimes mutilated too. In 1555, for instance, the executioner of Valenciennes, then part of the County of Hainaut, used a hot iron rod to pierce the tongue of a man who had been giving insults about 'l'execrable mot de bougrerye'. ${ }^{25}$ Others were even executed, as we have already seen in the case of Vander Poorten, who was decapitated after the Bruges' aldermen successfully petitioned their colleagues in Tournai for a severe penalty. ${ }^{26}$

\section{Gossiping about sodomy}

However, the deterrent effect of this strict approach must have been minimal, as many people continued gossiping about their acquaintances, including their deviant sexual habits. ${ }^{27}$ This was especially the case when women were concerned, who were more likely to be the victim of sexual defamation, whereas male insults generally focused on financial issues and dishonesty. ${ }^{28}$ In some examples, however, slander involved the so-called unmentionable vice, and occurred at all levels of society. Indeed, defaming political opponents as sodomites had become a well-established practice since the fourteenth century. ${ }^{29}$ One of the more famous examples of this strategy was the trial against the Knights Templar. In 1307, the French king Philip IV could not repay his debts to this infamous order; to avoid a financial scandal, the king accused the Templars of heresy and sodomy. As a result,

\footnotetext{
${ }^{23}$ Jean-Marie Moeglin, 'Pénitence publique et amende honorable au Moyen Age', Revue Historique 298 (1997), 226.

${ }^{24}$ Martine Veldhuizen, 'Guard Your Tongue. Slander and Its Punishment in a Late Medieval courtroom', in The Voices of the People, 242-43

${ }^{25}$ Lille, Archives départementales du Nord (ADN), Série B, no. 11891 (Prévôté de Vallenciennes, 1555-1556), fol. $17 \mathrm{v}$; Nathalie Demaret, 'Le bourreau: icône de la haute justice. Le maître des hautes oeuvres, la torture et les exécutions criminelles dans deux principautés en mutation: Hainaut et Brabant (ca. 1350- ca. 1570)', (PhD dissertation, Université Catholique de Louvain-La-Neuve, 2016), 316. On the mutilation of tongues: Elizabeth Ewan, “Tongue, You Lied". The Role of the Tongue in Rituals of Public Penance in Late Medieval England', in Edwin Craun (ed.) The Hands of the Tongue. Essays of Deviant Speech (Kalamazoo: Medieval Institute Publications, 2007), 129.

${ }^{26}$ In Switzerland too, several people were executed because of false sodomy accusations. Laura Stokes, Demons of Urban Reform. Early European Witch Trials and Criminal Justice, 1430-1530 (New York: Palgrave Macmillan, 2011), 158.

27 Lawrence Poos, 'Sex, Lies and the Church Courts of Pre-Reformation England', The Journal of Interdisciplinary History 25 (1995), 591.

${ }^{28}$ Trevor Dean, 'Gender and Insult in an Italian City: Bologna in the Later Middle Ages', Social History 29 (2004), 219; Laura Gowing, 'Gender and the Language of Insult in Early Modern London', History Workshop 35 (1993), 19.

${ }^{29}$ Jean Dunbabin, 'Treason, Sodomy and the Fate of Adenolfo IV, Count of Acerra', Journal of Medieval History 34 (2008), 428; Danielle Westerhof, 'Deconstructing Identities on the Scaffold: The Execution of Hugh Despenser the Younger, 1326', Journal of Medieval History 33 (2007), 94; James Brundage, 'The Politics of Sodomy: Rex V. Pons Hungh de Ampurias (1311)', in Joyce Salisbury (ed.), Sex in the Middle Ages. A Book of Essays (New York: Garland Publishing, 1991), 239-43.
} 
many Templars were arrested, tortured and executed while their order was dissolved by Clement V. ${ }^{30}$ The French king repeated this trick in 1310 when he posthumously charged pope Boniface VIII with sodomy following a lifetime of conflict. ${ }^{31}$ In fourteenth-century England on the other hand, the prince himself was the victim of gossip. The affectionate bond between Edward II (1284-1327) and his favourite Piers Gaveston was the subject of many rumours at court. ${ }^{32}$ In later centuries, kings such as James I of England and Henry III of France would share the same fate. ${ }^{33}$

In the Southern Netherlands too, courtiers knew the power of sodomite slurs. It was whispered that Louis II, Count of Flanders (1330-1384), repeatedly ignored the advice of his councillors and was instead greatly influenced by the 'merry young men' at his court. One chronicler mentioned how these youths regularly played music for the Count who favoured them with many gifts. ${ }^{34}$ Yet while Louis' supposed excessive attention for young men was only vaguely frowned upon, one of his fifteenthcentury successors was bluntly accused of sodomy. Charles the Bold, Duke of Burgundy (1433-1477), was praised for his bravery on the battlefield, yet his virility was sometimes questioned due to the fact that he fathered only one legitimate daughter and not even a single bastard.

This concern played directly into the hands of his half-brother, Baudouin of Burgundy, who was a central figure in a plot to murder Charles the Bold. When this plan prematurely unravelled in December 1470, Baudouin fled to the French court. To justify his sudden departure from the Burgundian Netherlands, he wrote a letter to the region's noblemen and dignitaries in which he accused Charles 'soy disant de Bourgogne' of 'gruesome abominations that directly went against God, law and the order of nature'. ${ }^{35}$ Baudouin continued by claiming that Charles had made him many indecent proposals and had even attempted to harass him. Because he refused to submit to Charles' unnatural advances, Baudouin feared that the Duke would take revenge on him, so he fled. Simultaneously, Jean de Chassa, another Burgundian nobleman who was also involved in the murder

\footnotetext{
${ }^{30}$ Anne Gilmour-Bryson, 'Sodomy and the Knights Templar', Journal of the History of Sexuality, 7 (1996), 15183; Richard Zeikowitz, Homoeroticism and Chivalry. Discourses of Male Same-Sex Desire in the Fourteenth Century (New York: Palgrave Macmillan, 2003), 107-29.

${ }^{31}$ Bernd-Ulrich Hergemöller, Sodom and Gomorrah: On the Everyday Reality and Persecution of Homosexuals in the Middle Ages (London: Free Association Books, 2001), 47.

${ }^{32}$ Claire Sponsler, 'The King's Boyfriend. Froissart's Political Theater of 1326', in Glenn Burger and Steven Kruger (eds.), Queering the Middle Ages (Minneapolis: University of Minnesota Press, 2001), 143-67.; Matthew Kuefler, 'Male Friendship and the Suspicion of Sodomy' in Matthew Kuefler (ed.), The Boswell Thesis: Essays on Christianity, Social Tolerance and Homosexuality (Chicago: The University of Chicago Press, 2006): 179214.

${ }^{33}$ Michael Young, King James and the History of Homosexuality (New York: New York University Press, 2000); Katherine Crawford, 'Love, Sodomy, and Scandal: Controlling the Sexual Reputation of Henry III', Journal of the History of Sexuality 12 (2003), 513-42. Rumours of same-sex desire remained omnipresent at the early modern French court. Nicholas Hammond, Gossip, Sexuality and Scandal in France (1610-1715) (Bern: Peter Lang, 2011).

${ }^{34}$ Jan van Dixmude, Dits de cronike ende genealogie van den prinsen ende graven van den foreeste van buc, dat heet Vlaenderlant, van 843 tot 1436 (Ypres: Lambin, 1839), 256.

${ }^{35}$ Paris, Bibliothèque Nationale de France (BNF), Manuscrit Français 5041, fol. 185r; Jean-Marie Cauchies, 'Baudouin de Bourgogne (v. 1446-1508), bâtard, militaire et diplomate. Une carrière exemplaire?', Revue du Nord 77 (1995), 263.
} 
plot, wrote a similar letter. According to Jean, Charles' sexual sins were 'so huge that a single word about them would pollute the air' ${ }^{36}$ The Duke of Burgundy regularly sinned against nature and wanted to involve Jean, so he saw no other option than to leave everything behind and escape to Paris. ${ }^{37}$ For Baudoin and Jean, as for many others who opposed early modern authorities, sodomy was a particularly useful political tool because the target's sexual sins symbolized how far they had transgressed the law in general, which legitimized possible rebellious actions.

Although gossiping about sodomy proved a useful tactic for dealing with political enemies, sexual intrigue was by no means limited to court circles. Even within some monastic walls rumours about the ungodly sin were deliberately spread during worldly disputes. In 1568, the Cistercian Abbey of Ter Duinen in the coastal region of Flanders was the setting of a contested abbot election. A number of monks opposed the newly elected Robert Holman as their abbot and spread word that Holman was a sodomite. An investigation was conducted under the leadership of the abbots of Ter Doest Abbey near Bruges and St. Peter's Abbey in Ghent. Confronted with these imposing ecclesiastical figures, almost none of the gossiping monks dared to repeat their original accusations, limiting themselves to the supposed financial upheavals that afflicted the monastery during Holman's time as treasurer. A number of them told an unlikely story in which Holman conceived a child with 'une morienne ou nègre blanche ${ }^{38}$ Unsurprisingly, the inquiry concluded that Holman had been unjustly accused. Finally, Holman was officially installed as the new abbot and the five or six monks who were the originators of the rumour were expelled from the monastery. Rumours of such deviant sexuality plagued many convents during the Reformation in the Low Countries, which was characterized by a strong anti-monastic sentiment. ${ }^{39}$ And yet, a remarkable facet of the era is that Catholic friars spread sodomite stories about individuals among their own ranks while the religious turmoil in the Low Countries was at its peak. This intriguing phenomenon illustrates that false accusations of sodomy were well ingrained in the Southern Netherlands.

Apart from any political or religious motives, a number of ordinary city dwellers had their own reasons to gossip about the unnatural sin. After all, sodomy was a capital offence that left behind few traces and, as such, it was an ideal way to damage one's reputation. Sometimes sodomy was even used as an escape route from an unhappy marriage, as a sixteenth-century case from Ath in the County of Hainaut shows. In 1552, Julyenne Lebevere accused her son-in-law, Michiel Berthe, of committing

\footnotetext{
${ }^{36}$ BNF, ms. 5041, fols. 180v-181r.

37 During the Burgundian Wars against the Swiss Confederacy (1474-1477), Charles the Bold was again defamed as a sodomite, as were his Lombard mercenaries. Helmut Puff, Sodomy in Reformation Germany and Switzerland (Chicago: The University of Chicago Press, 2003), 43-44.

${ }^{38}$ Brussels, National Archives of Belgium (NAB), Papiers d'Etat et de l'Audience, nr. 903 (Enquêtes abbaye des Dunes), fol. 178r-84r. Guy Dupont, 'De monnik, de non en de wellust van het vlees. Lichamelijkheid en seksualiteit bij de middeleeuwse cisterciënzers', Tijdschrift voor Geschiedenis 112 (1999), 168.

${ }^{39}$ Jonas Roelens, 'From Slurs to Silence? Sodomy and Mendicants in the Writings of Catholic Laymen in Early Modern Ghent', The Sixteenth Century Journal 46 (2015), 634.
} 
'le detestable crieme de sodommie' with his wife Marie. She was allegedly taken against her will 'par la partie posterieure'. Michiel was arrested while Marie was examined by a physician and midwives who found physical evidence of the abuse. Michiel confessed under torture to having engaged in anal intercourse with his wife four times, upon which he was sentenced to burn at the stake. Luckily for Michiel, the local hangman had left the region to carry out another execution, which gave Michiel's parents enough time to call the proceedings into question. They claimed that the testimony of Julyenne, Michiels's mother-in-law, was anything but reliable because she had previously solicited several people to kill Michiel. Furthermore, Michiel's parents accused her of sorcery. It is interesting to note how the defendants in this case retorted with the same tactic, slandering the accusers, and thus completely undermining their credibility. With this new information, mother and daughter were arrested too and, after a lot of bickering, a conspiracy was exposed. Apparently, Marie had a secret lover, and in order to be rid of her husband, she falsely accused him of sodomy. To make her lie more convincing, she even went so far as to 'torment herself with a stick in the bottom'. ${ }^{40}$ In the end, the cuckolded Michiel was released without further ado. His mother-in-law, however, was burned at the stake, while his wife and her secret lover were hanged. ${ }^{41}$ Apparently, the authorities did not trifle with false sodomy accusations either.

And yet, the case of Michiel Berthe was not unique. ${ }^{42}$ Nearly a century earlier, some women in Bruges unsuccessfully tried the same strategy. In 1473-1474, Katherine falsely accused her merchant husband, Jehan vanden Leene, of sodomy with his servant 'out of malice, great hatred and envy, and because she wanted to destroy her husband totally'. ${ }^{43}$ Apparently, she told several people that Jehan and his servant both deserved to end up at the stake. Shortly afterwards, Jehan was arrested by the bailiff. Confronted with her husband, the bailiff reminded Katherine of her statements, which she now denied. Katherine claimed that she had not really known what 'le grant mal' that she had accused Jehan of meant. She made her false accusations 'out of anger because they could not live together peacefully, and because her husband had also said that she deserved to end up at the stake'. Because of Katherine's good reputation in her neighbourhood, and the fact that it was public knowledge that Jehan insulted her on a daily basis, the bailiff decided to let her off with a mild fine. Whether or not Katherine exactly knew what sodomy entailed, she must have been well aware of the potential consequences of the 'unmentionable vice,' since she explicitly referred to the stake. Katherine may have followed the example of Jehanne, wife of Arnoulf Sey, who had also unjustly accused her

\footnotetext{
${ }^{40} \mathrm{NAB}$, Chamber of Accounts (CB), 14951, fols. 43r.

${ }^{41}$ Demaret, 'Le bourreau', 169-71.

${ }^{42}$ In 1530, Joozyne, wife of Gillis van Hulle, was banished from the County of Flanders for fifty years because she had dishonestly claimed that Gillis sodomized their seven-year-old son and three-year-old daughter. Ghent, City Archives (CAG), Series 212, no. 1 (Ballincbouc 1473-1537), fol. 215r.

43 NAB, CB, 13780, fol. 40r.
} 
husband of sodomy in the same year. Unlike Katherine, Jehanne was publicly exposed on the scaffold for two days because of her deceit. ${ }^{44}$

However, it was not just women looking for a clean marital slate who defamed others as sodomites. ${ }^{45}$ Although the reasons for these sexual slurs are not always clear, in some cases people were driven by utter resentment to spread false rumours. During a quarrel at an inn, Jacques Caillie publicly defamed his sister-in-law Marie as a witch, upon which she promptly claimed that Jacques was a 'bouggre ou fouteur de vaches', and that she had caught him several times red-handed with his pants to his knees standing on a stool behind his cow. Both were arrested because of the rumours they had been spreading about each other. Several interrogations later, both maintained their positions even though no evidence could be found for any of the allegations. On Christmas Eve 1614, both were released from prison but ordered to immediately leave the Franc of Bruges, never to return. ${ }^{46}$

Although the previous examples mainly featured women, men also used false sodomy accusations to ruin the reputation of others. In 1499, Pierre Lancedonc from Ghent for instance, accused Jehan Hanneman of bestiality with a mare. Although Jehan was interrogated three times, he insisted that he was innocent, after which Pierre was banished for fifty years. ${ }^{47}$ Lowijs van Maert from Bruges was wrongly accused of sodomy with his servant. The person responsible for this rumour was put on the scaffold for two days in $1465 .^{48}$ While it is not always clear how such local gossip ended up the subject of legal proceedings, in some cases the accused themselves went to court to clarify the matter. ${ }^{49}$ This was exactly what carpenter Jan Zeleman did in 1509 when Pierre Werrin, who was a weaver, told several people that Jan had engaged in several 'dishonourable and impure sorts of enormous things unworthy of public mention'. ${ }^{50}$

Yet the fact that sodomy appears to have been a popular slur in the Southern Netherlands is actually rather surprising. Usually, defamations were more or less gendered, but here, men were often

\footnotetext{
${ }^{44}$ NAB, CB, 13780, fol. 20r; Boone, 'State Power', 148. For examples of sodomy accusations used in domestic conflicts: Joanne Ferraro, Marriage Wars in Late Renaissance Venice (Oxford: Oxford University Press, 2001), 85; Ferraro, Nefarious Crimes, Contested Justice. Illicit Sex and Infanticide in the Republic of Venice, 1557-1789 (Baltimore: The Johns Hopkins University Press, 2008), 74, 93; Trevor Dean, 'Sodomy in Renaissance Bologna', Renaissance Studies, (forthcoming).

${ }^{45}$ In 1459 for instance, a certain Cateline defamed Pierkin de Naghele as a sodomite in Ypres. Neither Cateline's relation to Pierkin nor the reason for her false accusation is known, yet it led to a high fine of 60 pounds. NAB, CB, 14549, fol. 165r.

${ }^{46}$ Bruges, State Archives in Bruges, INV16 (Archives of the Franc of Bruges), no. 17042 (Registers van vervolgingen en invrijheidsstellingen, 1609-1614): fols. 228r-36v; Jos Monballyu, "Van vuylle faycten ieghens de nature'. Bestialiteitsprocessen in het graafschap Vlaanderen op het einde van de $16^{\text {de }}$ en het begin van de $17^{\text {de }}$ eeuw', Biekorf 100 (2000), 164-66.

${ }^{47} \mathrm{NAB}, \mathrm{CB}, 14115$, non-foliated.

${ }^{48}, \mathrm{NAB}, \mathrm{CB}, 13778$, fol. $45 \mathrm{v}$.

${ }^{49}$ Bariša Krekić, 'Abominandum Crimen: Punishment of Homosexuals in Renaissance Dubrovnik', Viator 18 (1987), 342.

${ }^{50} \mathrm{CAB}$, Series 192, no. 1 , fol. 53v.
} 
the subject of sexual slurs too. ${ }^{51}$ During verbal disputes, 'buggery' was invoked among antagonists. On January 25 1598, for instance, two messengers from Bruges stopped at a tavern in Ghent where they ran into a soldier from Bruges. The three fellow-citizens raised their glasses together, but they were interrupted by Noë Van Damme, a notorious drunkard from Ghent. When the soldier joked that all Ghentians were 'noose-bearers', Van Damme quickly replied: 'if we Ghentians are noose-bearers, then all those from Bruges are buggers, ${ }^{52}$ These mutual insults lead to a fight and, as a result, Van Damme was sentenced to an amende honorable. After he had begged God and Justice for forgiveness, he was imprisoned for two weeks and put on bread and water. ${ }^{53}$ Van Damme was not the only one to use the term 'bugger' during quarrels, as it proved to be a popular insult when drunken Spanish soldiers came to blows with local citizens in the Southern Netherlands. ${ }^{54}$ Such incidents indicate that sodomy was a popular insult during early modern disagreements, which likely contributed to the ease with which someone could be falsely indicted for sodomy.

These false accusations and rumours are revealing in several ways. On the one hand, they force us to reconsider the veracity of early modern trial records in general. They are not to be understood as literal representations of the actual truth. ${ }^{55}$ What early modern people said in and outside court was influenced by particular circumstances. ${ }^{56}$ As the previous cases show, some putative witnesses had hidden agendas that influenced their testimonies. Furthermore, not everyone who was falsely accused was resilient enough to undergo interrogation under torture without confessing to crimes they did not commit. If the executioner had not been absent in the case of Michiel Berthe, for instance, his parents would not have had time to bring the conspiracy against their son to light and Michiel -who had confessed under torture- would have been classified in the sources as a sodomite. Indeed, a certain number of people must have achieved their goal by wrongfully -yet successfullyaccusing someone of sodomy.

On the other hand, these pieces of gossip are very revealing in the sense that they illustrate how familiar urban communities in the Southern Netherlands were with the concept of sodomy. According to Alan Bray, the theological status of sodomy as a cosmic sin and unmentionable vice made it difficult for early modern individuals to recognize specific same-sex acts as sodomy. ${ }^{57}$ Indeed,

\footnotetext{
${ }^{51}$ Niki Timmermans, 'Goede name ende fame. Verbale beledigingen in Brugge (1559-1633),' Biekorf 110 (2010), 36.

${ }^{52}$ CAG, Series 214 (Bouc vanden Crime), no. 14, fol. 120v.

53 Ibid, fol. 124r.

${ }^{54}$ Leuven City Archives, register 9747 (criminele processen 1600-1685), non-foliated; CAG, Series 207 (register van criminele informatien), no. 2, non-foliated; CAG, Series 213 (criminele processtukken), no. 1, non-foliated; CAG, Series 213, no. 11, non-foliated.

${ }^{55}$ Nathalie Zemon Davis, Fiction in the Archives. Pardon Tales and their Tellers in Sixteenth-Century France (Stanford: Stanford University Press, 1987), 4-5; Walter Prevenier and Peter Arnade, Honor, Vengeance, and Social Trouble: Pardon Letters in the Burgundian Low Countries (Ithaca: Cornell University Press, 2015), 4-6.

${ }^{56}$ Elizabeth Cohen, 'She Said, He Said: Situated Oralities in Judicial Records from Early Modern Rome', Journal of Early Modern History 16 (2012), 415.

${ }^{57}$ Alan Bray, Homosexuality in Renaissance England (New York: Columbia University Press, 1995), 76.
} 
it is rather doubtful that every city dweller had mastered the theological subtleties surrounding the complex concept of sodomy. Yet based on the sodomy allegations discussed above, it seems that urban society was well aware of the potential consequences of such a charge. In many cases, people actively used sodomy allegations to make life difficult for their political enemies, economic rivals or hated husbands. Furthermore, these false accusations suggest that the input of urban society was a key factor during sodomy trials and that denouncing people for unnatural acts was a common practice in the Southern Netherlands. Consequently, rumours about sodomy can provide information about who exactly demanded the strict persecution of deviant sexual acts in early modern urban society.

\section{Suspicious communities or severe authorities?}

Once the authorities established that an individual was wrongfully accused of sodomy, the slanderer concerned was heavily punished and the victim was rehabilitated. ${ }^{58}$ Sometimes the accused even received financial compensation for the stain of sodomy left on their reputation. In 1457, Loij Fockedeys received no less than six 'golden lions' from Bruges' city council as a compensation for the damages caused by false accusations of 'buggery'. ${ }^{59}$ Having determined that Jehan Claeis from Melsele had been imprisoned for 24 days on suspicion of sodomy in 1572 'sur faulses accusations et rapports', he recompensed with eight shillings for every day he was jailed. Remarkably enough, this compensation was even higher than the expenses resulting from his imprisonment, which mounted to six shillings per day. ${ }^{60}$ Clearly, civic rulers were committed to restoring the honour of victims of spurious sodomy accusations. By adequately punishing the gossiping perpetrators, the authorities made it clear that falsely defaming others as sodomites was simply unacceptable.

At the same time, however, early modern authorities across Europe often encouraged individuals to turn in sodomites, because of their supposed danger to the social fabric. Portuguese law offered people who denounced sodomites a part of their confiscated property in recompense, ${ }^{61}$ while the Venetian city council at one point even granted immunity to active sodomites who informed against their passive partner. ${ }^{62}$ In the Southern Netherlands too, people were sometimes actively encouraged to come forward with stories about unnatural sexual desires. During doorgaande waerheden, the bailiff went from parish to parish with a questionnaire to assess which crimes had remained unpunished that year, offering members of urban communities a perfect opportunity to

\footnotetext{
${ }^{58}$ In 1509, Werrin had to beg Zeleman for forgiveness on his knees and was whipped with rods and banished afterwards., CAB, Series 192, no 1, fol. 53v.

${ }^{59}$ CAB, Series 157, no. 2 (Civiele Sententies, 1453-1460), fol. 167r.

${ }^{60}, \mathrm{NAB}, \mathrm{CA}, 14480$, fol. 10v.

${ }^{61}$ Harold Johnson and Francis Dutra, 'Introduction', in Johnson and Dutra (eds.), Pelo Vaso Traseiro. Sodomy and Sodomites in Luso-Brazilian History, (Tuscon: Fenestria Books, 2007), 6.

${ }^{62}$ Patricia Labalme, 'Sodomy and Venetian Justice in the Renaissance', Tijdschrift voor Rechtsgeschiedenis, 52 (1984), 227.
} 
blacken each other. ${ }^{63}$ In the city of Kortrijk, sodomy figured high on local bailiff's list of priorities. His questionnaire contained 36 questions on crimes ranging from illegal dumping to witchcraft, and prominently in second place was the question: "who is infamous for buggery? ${ }^{64}$ This indicates that the authorities considered it quite likely that someone in the local community would accuse an acquaintance of sodomy. Unfortunately, the majority of these question lists have not survived, making it difficult to ascertain whether the situation in Kortrijk was exceptional or not.

Due to a lack of sources, it is equally difficult to determine if the population actually responded to such appeals. ${ }^{65}$ In early modern Aragon, for instance, they did: no less than 96 per cent of all sodomy cases tried by the Inquisition were the result of accusations made by locals. ${ }^{66}$ In the Southern Netherlands, denouncing neighbours were responsible for the bulk of witchcraft and heresy accusations- crimes, not coincidentally, for which the burden of proof rested on testimonial evidence. Sodomy, on the other hand was hardly ever discussed in great detail in early modern trial records, and it is generally not known how sodomy cases came to court in the Southern Netherlands. Several accounts refer to men who were sexually harassed by other men. They went to court to charge the initiators of the deviant desires and to establish their own innocence of such matters. However, samesex acts between consenting partners rarely came to light and thus the authorities had to rely on the vigilance of the urban community to uncover when sodomy was committed. ${ }^{67}$ Yet even when lurking neighbours came across 'unnatural' sexual acts, this did not necessarily mean they felt that handing over the perpetrators to the authorities was the best way to deal with the matter.

Indeed, certain cases reveal a willingness within urban communities to punish sexual scandals without the official intervention of the city council. ${ }^{68}$ In 1620 , Cornelis Cornelis drove a manure cart

\footnotetext{
${ }^{63}$ Egied Strubbe, 'Het houden van de doorgaande waarheid in het Vrije van Brugge', Handelingen van het Genootschap voor Geschiedenis te Brugge 66 (1923), 249-53.

64 'Wie berucht es van bogghernien...' Thierry De Limburg-Stirum, Ville de Courtrai (Brussels: Goemaere, 1905), 303.

${ }^{65}$ In the preserved statements made during doorgaande waarheden from 1474 until 1517 in 'het Oostproosse,' the part of the ecclesiastical manor of 'het Proosse' that lay within Bruges' city walls, sodomy was never discussed. In the Northern Netherlands however, several cases survive in which the urban community handed over sodomites the authorities at their request. During episcopal visitations, the local priest appointed certain parishioners who had to denounce people violating church regulations, a ritual known as the seend or synod. In 1454, a man from Utrecht was sentenced to the stake together with his partner who originated from the Southern Netherlandish city of Mechelen. A.J.A. Bijsterveld, 'De kerk in het midden. De parochiekerk als centrum van de middeleeuwse dorpsgemeenschap', Noordbrabants Historisch Jaarboek 17-18 (2000-2001), 107; Regnerus Post, Kerkelijke verhoudingen in Nederland vóór de Reformatie van \pm 1500 tot \pm 1580 (Utrecht: Spectrum, 1954), 438.

${ }^{66}$ Cristian Berco, 'Social Control and its Limits: Sodomy, Local Sexual Economies, and Inquisitors during Spain's Golden Age', The Sixteenth Century Journal 36 (2005), 340.

${ }^{67}$ Carl Hoffmann, 'Social Control and the Neighborhood in European Cities', in Herman Roodenburg and Pieter Spierenburg (eds.), Social Control in Europe. Volume 1: 1500-1800 (Columbus: The Ohio State University Press, 2004), 313; Elwin Hofman, 'An Obligation of Conscience: Gossip as Social Control in an EighteenthCentury Flemish Town', European Review of History 21 (2014), 661.

${ }_{68}$ Anne-Marie Kilday, 'Hurt, Harm and Humiliation. Community Responses to Deviant Behaviour in Early Modern Scotland', in Judith Rowbotham, et al (eds.), Shame, Blame, and Culpability: Crime, Violence, and the
} 
pulled by a grey mare into Denderhoutem, a small village near Ghent. Thinking he was unobserved, he committed 'the detestable and abominable offense called the crime against nature' with the said mare. Cornelis was caught in flagrante delicto by two men however. They immediately ordered him to move away from the horse, scolded him for being a knave and beat Cornelis with sticks. ${ }^{69}$ The resultant turmoil brought the case to the court's attention. Yet we must assume that the two men who caught Cornelis thought that a good trashing was preferable to handing Cornelis over to the authorities. According to Theo van der Meer, many early modern sodomites had to deal with people's tribunals and were physically punished because the general public felt that the authorities did not act upon their complaints. $^{70}$

Perhaps this lack of confidence was not entirely unjustified. Historiography has drawn much attention to the traditional view of early modern state formation in which central governments vigorously asserted their authority over the moral behaviour of their subjects. ${ }^{71}$ In the Southern Netherlands, however, the princely authorities were less successful in controlling urban jurisdictions which retained a large degree of independence, ${ }^{72}$ and unlike the central government, these local authorities preferred reconciliation over punishment. ${ }^{73}$ Consequently, they were probably less keen to implement a strict persecution policy towards sodomites than we might assume. This could come as a surprise given the fact that in the early modern period sodomy was considered to be a heinous crime against nature, which could provoke God's wrath over entire cities through plagues, war, famines, floods earthquakes and so on. ${ }^{74}$ In other words, it was widely believed that society as a whole could be punished for the sexual sins of individuals. ${ }^{75}$ As such, civic authorities were responsible for the protection of the moral integrity of a community. ${ }^{76}$ Many city councils, however, had little interest in an overly harsh moral repression as they felt that it was their primary task to preserve social cohesion

Modern State (London: Routledge, 2014), 124-40; Martin Ingram, 'Charivari and Shame Punishments: Folk Justice and State Justice in Early Modern England', in Social Control in Europe, 288-308.

${ }^{69}$ Ghent, State Archives in Ghent, AR152 (Land van Rotselaar), no. 73, non-foliated.

${ }^{70}$ Theo van der Meer, Sodoms zaad in Nederland. Het ontstaan van homoseksualiteit in de vroegmoderne tijd. (Nijmegen: Sun, 1995), 329.

71 Pieter Spierenburg, The Spectacle of Suffering. Executions and the Evolution of Repression: From a Preindustrial Metropolis to the European Experience (Cambridge: Cambridge University Press, 1984), 44; Robert Muchembled, Le temps des supplices: de l'obéissance sous les rois absolus. XV $V^{e}$ XVIII siècle (Paris: Colin, 1992), 225.

${ }^{72}$ Maarten van Dijck, 'Tussen droom en daad. De beperkte invloed van de centrale overheid op de rechtspraktijk in Antwerpen en Mechelen gedurende de vijftiende en zestiende eeuw', in Dirk Heirbout et al (eds.), Histoire du droit et de la justice. Une nouvelle génération de recherches (Louvain-la-Neuve: Presses universitaires de Louvain, 2010), 299-317.

${ }^{73}$ Amanda Capern, 'Rumour and Reputation in the Early Modern English Family,' in Fama and her Sisters, 108. In some cases, however, the central authorities intervened to temper overzealous prosecutions of certain crimes, like witchcraft. Fernand Vanhemelryck, Het gevecht met de duivel. Heksen in Vlaanderen (Leuven: Davidsfonds, 2000), 292-93.

${ }^{74}$ Joos de Damhouder, Practycke ende handbouck in criminele zaeken (Roeselare: Den Wijngaert, 1981$), 169$.

75 Jonathan Goldberg, Sodometries: Renaissance Texts, Modern Sexualities (New York: Fordham University Press, 2010), 18-19.

${ }^{76}$ Jesu Angel Solorzano Telechea, 'Fama Publica, Infamy and Defamation: Judicial Violence and Social Control of Crimes Against Sexual Morals in Medieval Castile', Journal of Medieval History 33 (2007), 410. 
within urban society. Consequently, it was possible that a crime such as sodomy was strongly condemned in theory, without the government taking effective punitive measures. ${ }^{77}$ Since sodomy was a matter of public order, it only caught the attention of the authorities when it became a scandal and, therefore, a threat to public order.

In any case, it seems that most early modern civic authorities in the Southern Netherlands lacked an adequate approach for repressing sodomy. Even in Bruges, a city which Marc Boone rightfully categorized 'among Europe's most important centres for the repression of sodomy' ${ }^{78}$ the juridical system appears to have procrastinated somewhat. The Verluydboek, which listed the criminal sentences handed down by the city's aldermen, contains numerous entries regarding sodomy cases that were committed many years before ('zekeren jaren haerwaerts" ${ }^{, 79}$ ) they were actually brought to trial; Anthuenis Camelin, for instance, was executed in 1504 for 'several horrible kinds of the inhuman sin of sodomy' which he had committed no fewer than twelve years before. ${ }^{80}$ Such facts seem to indicate that the civic authorities in the region were lagging behind events rather than setting up systematic persecution.

Something similar occurred in early modern Frankfurt, where people were tried for same-sex acts they had committed several years earlier. According to Maria Boes, this was not the result of an ineffective prosecution policy, however, but the outcome of communal toleration. Local witnesses indicated in their testimonies that they did not find it necessary to inform the officials, even though they had been aware of the same-sex activities of the accused for quite a while. Boes concludes that 'popular mentality served as a protective shield against judicial intrusion' ${ }^{81}$ In the Southern Netherlands, on the other hand, there is little evidence of early modern 'sexual tolerance' or tacit consent. $^{82}$ Although it took a long time before some sodomy cases were actually punished, the 'crimes' concerned were often the talk of the town. Many trial records mention how people were notorious or infamous ('berucht' or 'befaempt') for their unnatural sexual acts. In 1514, for instance, Pieter Roesbot was questioned under torture twice by the hangman of Leuven because he was 'befaempt' for the crime of sodomy. As he refused to confess, Pieter was released. ${ }^{83}$ This indicates that suspects were arrested based on hearsay rather than on solid evidence and illustrates the importance of rumours, gossip and the participation of the urban community during early modern sodomy trials. People often policed each other's behaviour and gossiped about deviant sexuality to maintain the good

\footnotetext{
${ }^{77}$ Puff, Sodomy, 170.

${ }^{78}$ Boone, 'State Power', 135.

${ }^{79} \mathrm{CAB}$, Series 192, no. 1, fol. 16r.

${ }^{80}$ CAB, Series 192, no. 1, fol. 38v; NAB, CB, 13783, fols. 56v-57r.

${ }^{81}$ Maria Boes, 'On Trial for Sodomy in Early Modern Germany', in Tom Betteridge (ed.), Sodomy in Early Modern Europe (Manchester: Manchester University Press, 2002), 37.

${ }^{82}$ Actually, the term tolerance is problematic when applied to premodern societies. Klaus van Eickels, 'Why Minorities Were Neither Tolerated nor Discriminated Against in the Middle Ages', in Guðmundurva Hálfdanarson (ed.), Discrimination and Tolerance in Historical Perspective (Pisa: PLUS-Pisa University Press, 2008), 285-93.

${ }^{83} \mathrm{NAB}, \mathrm{CB}, 12660$, non-foliated.
} 
reputation of the local community. Consequently, passive authorities were often forced to intervene because of collective concerns about deviant sexuality. ${ }^{84}$

This was literally the case on the night of 26 July 1559 . When Nicolas de Pas got up to go to the lavatory in his backyard, he witnessed Pieter Coppen Jans having 'enormous and infamous affairs' with a dog. Nicolas informed his roommate Andries de Navarette from Toledo, who immediately jumped out of the window to assist Nicolas. In his haste to get to the crime scene, Andries even ripped the sleeves of his jerkin. Nicolas and Andries immediately gathered a large crowd, forced their way into Pieter's house, rescued the dog and handed Pieter over to the bailiff of Ghent. ${ }^{85}$ Despite their decisive action, neither the remaining trial records nor the bailiff accounts mention Pieter's punishment, so it appears that he went unpunished. Nevertheless, the case of Pieter Coppen Jans once more demonstrates how much civic authorities relied on their citizens to take action, and the willingness of urban society to do so by vigorously reporting sodomites to court.

The active participation of citizens in sodomy trials did not always imply a negative outcome for those involved. In the early modern period, verdicts depended to a large extent on the social reputation or fama of the accused. ${ }^{86}$ Local witnesses could therefore save lives when they were asked to testify about the reputation of the suspect in question. ${ }^{87}$ We already saw how Katherine vanden Leene, who defamed her husband as a sodomite, received just with a mild fine because of her good reputation. In 1392, an anonymous surgeon from Namur also benefitted from his respectable repute when accused of sodomy by a young Augustinian with whom he had shared a bed in a tavern during his travels. The surgeon was questioned two times by the local aldermen of Maubeuge, yet it was an enquiry among the residents of his hometown Namur that 'revealed his honesty' and ultimately acquitted him from all charges ${ }^{88}$ Local witnesses also intervened in the case of Michiel Weyns, who got arrested on suspicion of sexually harassing Thiery Dijcman in a tavern in Bruges during 14691470. Michiel confessed under torture that he had grabbed Dijcman's 'manliness', as he had done with other men in public bathhouses, yet he denied having sexual intercourse with them. The bailiff consulted the city's aldermen, who saw no need to prosecute Michiel Weyns because he appeared to be an elderly man with a good reputation ('autrement de bonne fame et renommee'). Weyns was let off with a fine, to the relief of several people and friends, who apparently had begged for his release. ${ }^{89}$

\footnotetext{
${ }^{84}$ Puff, Sodomy, 87.

${ }^{85}$ CAG, Series 214, no. 3, fol. 139r-v.

${ }^{86}$ Steve Hindle, 'The Shaming of Margaret Knowsley: Gossip, Gender and the Experience of Authority in Early Modern England,' Continuity and Change 9 (1994), 408-9; Laura Stern, 'Public Fame in the Fifteenth Century,' The American Journal of Legal History 44 (2000), 198.

${ }^{87}$ Barbara Hanawalt, 'Of Good and Ill Repute.' Gender and Social control in Medieval England (Oxford: Oxford University Press, 1998), ix; F.R.P. Akehurst, 'Good Name, Reputation, and Notoriety in French Customary Law', in Thelma Fenster and Daniel Lord Smail (eds.), Fama: The Politics of Talk and Reputation in Medieval Europe (Ithaca: Cornell University Press, 2003), 80-81; Renée Levine Melammed, 'The World of Witnesses and the Holy Tribunal: Fifteenth-Century Trials of Castilian Judaizers', in Voices from the Bench, 60.

${ }^{88}$ Lille, ADN, Série B, no. 11500 (Prévôté de Maubeuge, 1392-1393) fol. 18r.

${ }^{89}$ NAB, CB, 13779, fol. 22v.
} 
The same goes for Jannic Gielis from Vorst, who was falsely accused of sodomy in 1464. Allegedly, he had engaged in same-sex acts fourteen years before. Yet because Jannic was a respected man married for many years and father to four children- who could count on the support 'of many good men', he was released..$^{90}$ Consequently, local citizens played a key role during early modern sodomy trials. Whether it was by gossiping about suspicious encounters in their neighbourhood or by personally arresting and punishing sodomites, they often brought forbidden actions to the attention of the aldermen who indeed preferred not to take the initiative until popular demand forced them to do so.

\section{Conclusion}

The early modern legal status of fama suggests that a person's reputation was crucial evidence throughout Europe for centuries. That certain innocent people became the victim of slanderers as a result of this should not surprise. What is particularly surprising, however, is the fact that early modern gossipers in the Southern Netherlands did not hesitate to use the unspeakable sin to defame others, especially given the overall commitment to silencing talk of sodomy altogether in early modern society. Although sodomy was considered such a heinous crime it should not be mentioned among Christians, it turned out to be a popular topic in early modern rumours. Sodomite slurs were exploited politically or used during religious disputes. Gossiping about sodomy was no prerogative of the elite, however. Sodomite slurs were voiced throughout the Southern Netherlands for a variety of reasons. Ordinary citizens used them to get rid of an unwanted husband, to take revenge on an old enemy or to express their moral anxieties.

Early modern authorities took an ambiguous stance towards these rumours. False slander was punished almost as severely as the crime of sodomy itself, and yet, locals were sometimes encouraged to inform against sodomites. Despite these appeals, the cautious attitude of some city councils towards sodomy is particularly striking. Many sodomites were able to commit their 'crimes against nature' for many years before they were caught. That such cases still came to court after such a long period resulted from the fact that rumours about sodomy eventually reached the ears of the aldermen, who depended on the participation of the urban community to find out when and where 'the silent sin' was committed.

Early modern gossip can thus shed new light on the persecution of sodomy in several ways. On the one hand, false accusations force us to reconsider the potentially misleading character of early modern trial records. On the other hand, the fact that several people were punished for falsely accusing people of 'buggery', indicates that denouncing sodomites to the authorities was indeed a common practice in the Southern Netherlands. Slanderers must have followed the example of other accusations, whether justified or not, knowing that their rumours would sooner or later lead to a court case with a

${ }^{90} \mathrm{NAB}, \mathrm{CB}, 12680$, non-foliated. 
possibly fatal outcome. And while sodomy was unmentionable, many citizens made public their concerns about deviant sexual acts. In fact, the demand for a rigorous approach towards sodomy often came from within urban society, rather than from the proper officials. While some witnesses preferred to take the law into their own hands and punish sodomites personally, other bystanders physically intervened and made sure that sodomites caught in the act were handed over to the authorities. Moreover, many individuals were punished based on their reputation as sodomites rather than on hard proof. In other words, civic authorities often relied on their citizens to take action when sodomy was concerned. By taking a closer look at early modern gossip, this article argues that urban discourses on sodomy did indeed have a major impact on the repression of the 'unmentionable vice.' 